\title{
Purification of bacteriocins using size-exclusion chromatography
}

\section{Irfan A. Rather, Alshammari Fanar Hamad and Vivek K. Bajpai}

Department of Applied Microbiology and Biotechnology, Yeungnam University, Gyeongsan 712-749, South Korea.

Correspondence to Vivek K. Bajpai at vbiotech04@gmail.com

First Published: 13 March, 2016

DOI: 10.3329/bjp.v11i2.25862

\section{ABSTRACT}

The bacteriocin purification involves following main steps. a) Extraction of cell-free-supernatant of bacteria; b) Ammonium sulfate precipitation; c) Dialysis; d) Diafiltration using PVP and e) Size-exclusion chromatography. However, depending on the nature of work, the compound could be further analyzed by Reverse-phase HPLC, NMR, mass spectrometry and sequencing.

\section{INTRODUCTION}

Bacteriocins are a diverse group of antibacterial proteinacous compounds produced by bacteria in order to inhibit or suppress the growth of other bacteria. Among Gram-negative bacteria, colicins from E. coli are most studied. The colicins are antibacterial proteins which inhibit or kill closely related bacteria through disestablishing cell membrane, inhibiting cell wall synthesis or by inhibiting RNase or DNase activity. In case of Gram-positive bacteria such as lactic acid bacteria have been widely exploited for antimicrobial efficacies in food industries. However, the production cost of these antimicrobials is expensive due to optimized media composition and laborious purification process in addition to low yield in food-grade medium. Therefore, cost-effective medium and purification processes are of great need.

\section{MATERIALS AND EQUIPMENTS}

- Bacteria growth media

- Centrifuge tubes (depends on volume)

- Millipore steritop ${ }^{\mathrm{TM}}$ sterile vacuum filter unit

- Ammonium sulfate

- Motor and pistol

- Disposable pipette

- Ice and tray

- Dialysis bag and tubing closure

- $20 \mathrm{mM}$ phosphate buffer $\mathrm{pH} 7$

- Falcon ${ }^{\mathrm{TM}} 50 \mathrm{~mL}$ conical centrifuge tubes

- Polyvinylpyrrolidone

- Aluminum foil 
- Refrigerated centrifuge

- Suction pump

- Distilled water

- 1-10 open jars or beakers

- Sephadex G-25 column (Sigma-Aldrich)

- Plain reusable glass tubes $(10 \mathrm{~mL})$

- Automatic fraction collector model 2110 (BIO-RAD)

- Magnetic stirrer

\section{PREPARATION OF REAGENTS}

Bacteria growth media: Dissolve $56 \mathrm{~g}$ of MRS media (for lactic acid bacteria) in 1 liter of distal water, stirrer until it gets properly dissolved and autoclave it.

Buffer: For fast and error free calculations of buffer with desired $\mathrm{pH}$, use buffer calculators, for example (http://clymer.altervista.org/buffers/phos2.html or (http://www.biomol.net/en/tools/buffercalculator.htm).

\section{VIDEO CLIPS}

$\begin{array}{ll}\text { Part 1: } & 4 \min 52 \mathrm{sec} \\ \text { Part 2: } & 1 \mathrm{~min} 47 \mathrm{sec}\end{array}$

\section{METHOD}

Ammonium sulfate precipitation:

It is a simple method to precipitate proteins without causing denaturation. There are some critical points to take care of during ammonium sulfate precipitation.

- Grind ammonium sulfate into small fine particles.

- Slowly add ammonium sulfate (pinch by pinch) into the liquid at cold temperature, adding salt at higher amount will result in wrong proteins to be precipitated.

- Stir the solution throughout the process of precipitation to fully equilibrate.

- Avoid creating air bubbles as that will result in denaturing proteins.

Adding ammonium sulfate to your sample is easier; however, it is time consuming to calculate how much amount you need to for desired percentage saturation. Therefore, we use the following program to calculate the amount of solid ammonium sulfate required for a definite volume to get a definite percentage of saturation at a specific temperature.

http://www.encorbio.com/protocols/AM-SO4.htm

Protein dialysis:

Dialysis is nothing, but removal of small unwanted compounds from a solution through a semi-permeable membrane. A sample inside membrane is allowed to diffuse against a buffer solution (at least 200-fold greater than the sample volume). It is important to use membrane with known pore size. During dialysis, small molecules and salts that are small than the pore size of membrane pass through the membrane, while as molecules with larger pore size than the membrane retain inside the membrane. Following are some of the important points to be taken care during dialysis.

- Before adding sample to dialysis membrane, it is highly recommended to wash the membrane with ultrapure water or buffer for at least $30 \mathrm{~min}$ to remove contaminants such as sulfur, heavy metals and glycerol to avoid any possible effects of these components on sample. 
- Dialysis is faster at higher temperature (e.g. room temperature) and slower at lower temperature (e.g. $4^{\circ} \mathrm{C}$. So, before selecting temperature it is therefore important to know the thermal stability of your protein. For example, doing thermal stability test of crude sample at different temperatures will give an idea of stability of our compound (e.g., bacteriocin).

- In addition, the rate of dialysis also depends on surface area of the membrane as well as the concentration of molecule. Therefore, it is recommended using bigger flasks to carry out dialysis on magnetic stir with regular buffer exchange.

\section{PROTOCOL}

1. Grow the bacteriocin producing bacterium in 1 liter of MRS broth and incubate it at $37^{\circ} \mathrm{C}$ for 24 hours.

2. Centrifuge the culture at $12,000 \mathrm{xg}$ for 10 to $15 \mathrm{~min}$ to pellet down the cells.

3. Filter sterilizes the supernatant using micro filter (Millipore).

4. Bring the supernatant to a final concentration of $80 \%(\mathrm{w} / \mathrm{v})$ saturation of ammonium sulfate.

5. Divide the mixture into $50 \mathrm{~mL}$ test tubes (depends on the volume) and centrifuge at 10,000 xg for 10$15 \mathrm{~min}$ at $4^{\circ} \mathrm{C}$ to pellet down protein. It is recommended to weight the test tubes before centrifugation, make sure each tube contains equal amount of sample.

6. Carefully, discard the supernatant and to the pellet add $500 \mu \mathrm{L}$ to $2 \mathrm{~mL}$ phosphate buffer to dissolve pellets (try to use minimum volume of buffer to the dissolve the pellet. While dissolving pellet store the tubes at $4^{\circ} \mathrm{C}$ or use ice to maintain the temperature.

7. Load the sample into dialysis tubing. Dialyze for two hours and change the buffer. Dialyze another two hours and change the buffer and dialyze overnight at $4^{\circ} \mathrm{C}$.

8. After dialysis diafilterate the dialysis membrane with polyvinylprrolidone (PVP) over night at $4^{\circ} \mathrm{C}$ to inhibit protein adsorption on membrane surface and to remove polyphenols and access water in the sample.

9. Collect the sample in a centrifuge tube and load the appropriate volume in column.

10. Collect the column fractions manually or using automatic fraction collector.

11. Check the activity of each fraction.

12. Depends on the nature of the work; the active fraction can be further analyzed by Reverse-phase HPLC, NMR, mass spectrometry and sequencing.
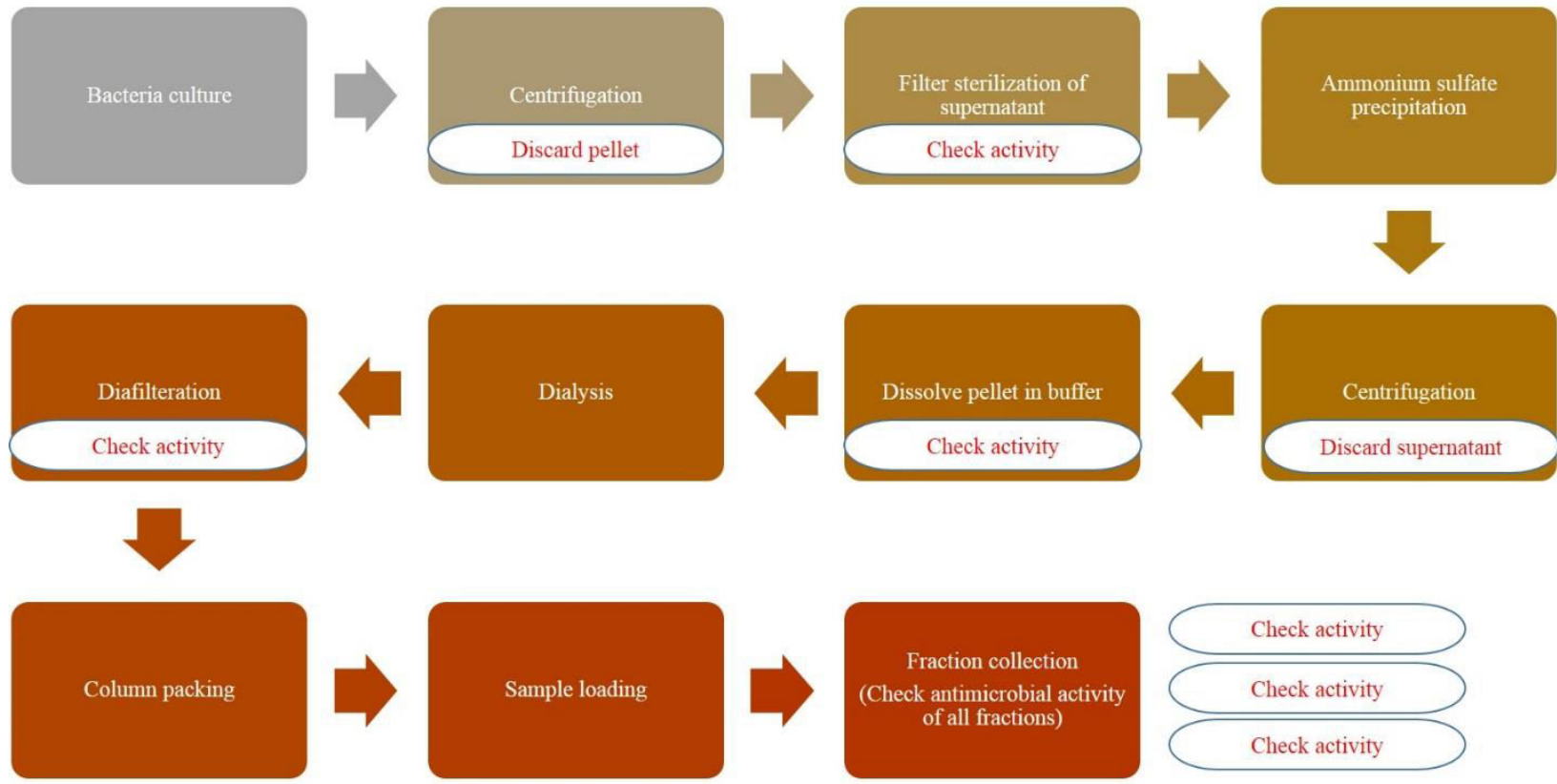

Figure 1: Flow chart of bacteriocin purification 


\section{DISCUSSION}

There are different techniques available that can be applied for the purification of bacteriocins. In this paper, we showed one of the methods used to purify bacteriocins. The method of purification depends on the size and nature of a compound. It is always recommended to try different methods of purification and check the detection and recovery of bacteriocin. One of the major drawbacks of purification is cost effective and time consuming. However, LAB producing bacteriocins have received considerable interest over the past couple of years because of its use as food preservative.

\section{REFERENCES}

Ammonium sulfate calculator. EnCor Biotechnology Inc. 2015.

Gel filtration principles and methods. Amersham Biosciences. 18-1022-138.

\section{PRECAUTION}

It is important to check the temperature and buffer stability of your sample of interest before purification. In addition, choose the right column for your sample. Never allow column to dry. Column packing is one the important steps in purification, carefully pack column. 


\section{Your feedback about this paper}

1. Number of times you have read this paper 0

2. Number of times you have seen the video clip 0

3. Which video you may need to see again, if any

4. Quality of paper

$\bigcirc$ Excellent $\bigcirc$ Good $\bigcirc$ Moderate $\bigcirc$ Not good

5. Your comments 